\title{
EFFECT OF GEOMETRIC IMPERFECTIONS IN THE SHAPE OF BUCKLING FORM ON THE REDUCTION OF LOAD CAPACITY OF CYLINDRICAL SHELL
}

\author{
K. SCHABOWICZ ${ }^{1}$, L. ZAWIŚLAK ${ }^{2}$,
}

\begin{abstract}
The approach to numerical analyses was changed by the introduction of Eurocodes . The EN 1993-1-6 standard allows taking into account imperfections on the shape of a buckling form from a linear elastic bifurcation analysis. The article analyses the first ten forms of imperfection from a linear elastic bifurcation analysis on the reduction of the capacity of a cylindrical shell. Calculations were made using finite element methods.
\end{abstract}

Keywords: Numerical analysis, cylindrical shells, imperfections.

\section{INTRODUCTION}

Thin cylindrical shells are widely used in civil engineering as silos, tanks, etc., but only the numerical methods allowed for a good estimation of their bearing capacity at the design stage. Due to the low wall thickness, these shells are very vulnerable to loss of stability, it is also one of the condition for determining the load capacity in accordance with EN 1993-1-6 standard [1]. Due to the very large slenderness of the walls, it is important at the design stage to take into account geometric imperfections (ovalization, dentures, etc.), in addition to geometric imperfections, which most affect the reduction of the load capacity of such a shell, we also distinguish material imperfections and other imperfections (among others, residual stresses). The bifurcation buckling theory Timoshenko, S. P., (1961) [4] predicts the loss of stability of

\footnotetext{
${ }^{1}$ Prof. WUT, PhD, DSc, Eng., Wrocław University of Science and Technology, Faculty of Civil Engineering, Department of Construction Technology, Wybrzeże Wyspiańskiego 27, 50-370 Wrocław, Poland, e-mail: krzysztof.schabowicz@pwr.edu.pl, ORCID: 0000-0001-6320-9539

2 MSc., Eng., Wrocław University of Science and Technology, Faculty of Civil Engineering, Department of Construction Technology, Wybrzeże Wyspiańskiego 27, 50-370 Wrocław, Poland, e-mail: lukasz.zawislak@pwr.edu.pl, ORCID: 0000-0003-2828-5899
} 
the ideal shell (without imperfections) taking into account axial compression. The studies of Athiannan, K. and Palaninathan, R. (2004) [5], led to the following conclusion: the form and location of the imperfection is more important than its value. In addition, Athiannan, K. (2004) [5] showed that the capacity of the actual thin cylindrical shell is reduced by almost one third (including deficiencies and imperfections) in relation to the ideal shell.

The introduction of the EN 1993-1-6 standard [1] was a very important step for providing requirements for the calculation of steel shells with numerical methods and systematized the naming of computational analyses. The standard [1] refers to several types of analyses to determine the final load capacity of the shell, namely:

- Linear elastic bifurcation analysis (LBA),

- Materially nonlinear analysis (MNA),

- Geometrically nonlinear elastic analysis (GNA),

- Geometrically and materially nonlinear analysis (GMNA),

- Geometrically and materially nonlinear analysis with imperfections (GMNIA).

In the case of some types of silos, the EN 1993-4-1 standard [2] imposes the obligation to use numerical analysis on designers, these are silos with the consequence class CC3, other classes of consequences can be calculated with the methods specified in the EN 1993-4-1 standard [2].

The EN 1993-1-6 standard [1] introduces four limit states:

- LS1 - plastic limit,

- LS2 - cyclic plasticity,

- LS3 - buckling,

- $\quad$ LS4 - fatigue buckling.

Inclusion of imperfections is required in the limit state of buckling LS3.

The EN 1993-4-1 standard [2] introduces the possibility of adopting the imperfection distribution corresponding to the buckling form of the linear elastic bifurcation analysis, but does not provide any additional information on the acceptance of the distribution. The objects such as shells, have infinitely many forms of stability loss. The article performed further analyses in order to determine the capacity of the shell in terms of its behaviour under load, the next step was to adopt various forms of loss of stability from the LBA analysis as initial imperfections, as shown below. 


\section{NUMERICAL MODEL OF A CYLINDRICAL SHELL.}

For the purposes of the analyses described in point 1 , it is required to create a numerical model of the shell, which will be loaded with a unit load. In the first step, the geometry of the shell will be selected, the load that will affect the structure and material model from which it will be made.

\subsection{ADOPTION OF GEOMETRY AND SHELL LOAD.}

The shell geometry was supported singularly - four locations - Fig. 1. The height of the considered shell of $2000 \mathrm{~mm}$, thickness of a wall of $1 \mathrm{~mm}$, diameter of a shell of $1000 \mathrm{~mm}$ was assumed.

Two types of boundary conditions were used:

- direction $U z=0$ was blocked in four locations - it simulates the local support, - direction $\mathrm{Ur}=0$ was blocked - it simulates the bottom and roof.

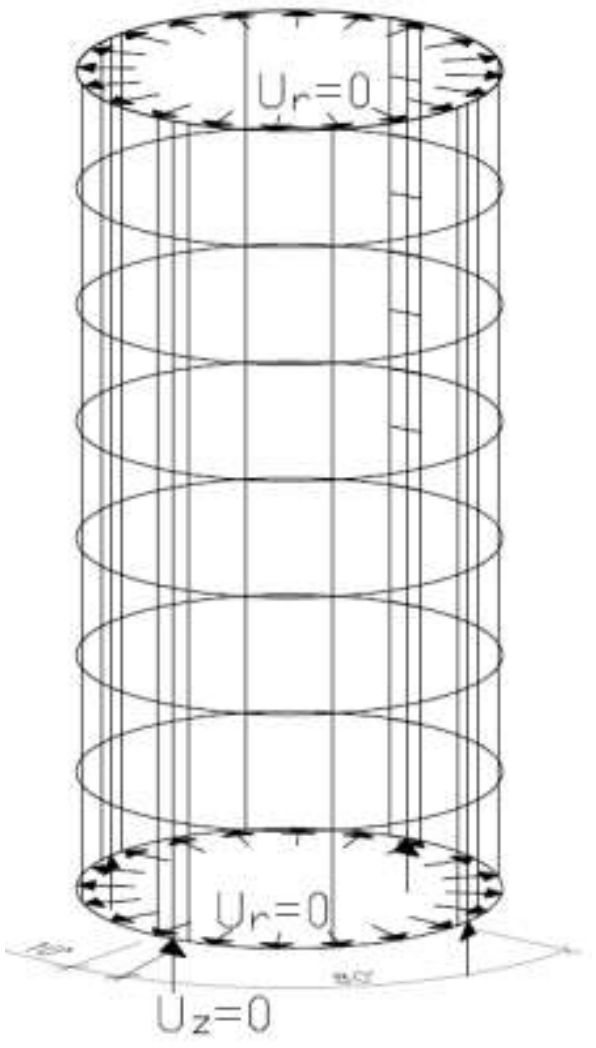

Fig. 1. Model geometry.

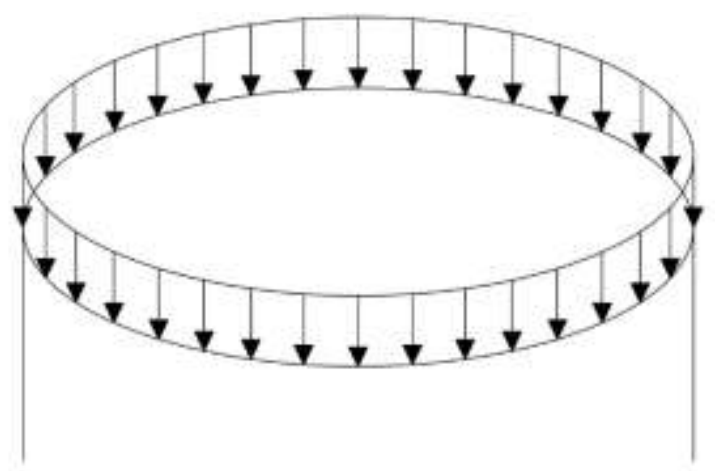

Fig. 2. Shell load diagram.

A unit load of $1 \mathrm{~N} / \mathrm{mm}$ was assumed, applied to the top edge of the considered shell - the load distribution is shown in Fig. 2. Total load acting on the considered shell:

$$
2 \cdot \pi \cdot 500 \mathrm{~mm} \cdot 1 \mathrm{~N} / \mathrm{mm} \approx 3141.59 \mathrm{~N}
$$




\subsection{ADOPTION OF THE SHELL MATERIAL MODEL.}

The material from which the cylindrical shell is made was adopted as steel with the Young's modulus E=210 GPa model, Poisson's ratio $v=0.3$ and yield strength of $235 \mathrm{MPa}$.

For the purposes of the linearly elastic bifurcation analysis (LBA) and geometrically nonlinear elastic analysis (GNA) the material model was applied a linear elastic material.

For the purposes of materially nonlinear analysis (MNA), geometrically and materially nonlinear analysis (GMNA), geometrically and materially nonlinear analysis with imperfections (GMNIA), a linear elastic-ideal plastic relations was used, as given in the EN 1993-1-1 standard [3] - Fig. 3.

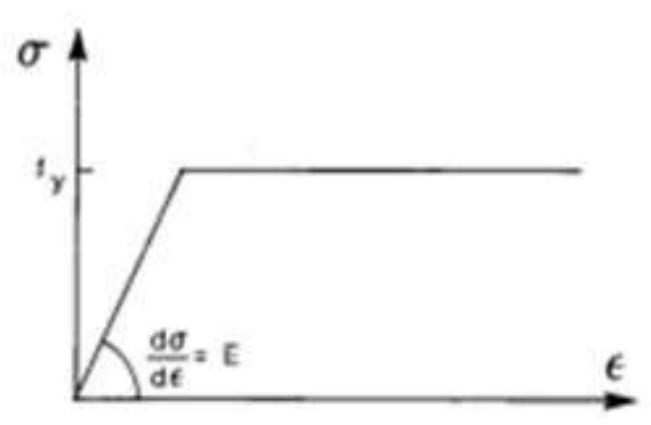

Fig. 3. Linear elastic-ideal plastic relations. Source: standard EN 1993-1-1 - figure 5.8 [3].

\subsection{ADOPTION OF THE NUMERICAL SHELL MODEL.}

The Simulia FEA System was used for creating the shell model, using the finite elements method. Creating a finite element mesh, it was refinement in the zones of expected buckling. In the support bands, S4R elements (4-node, quadrilateral, stress/displacement shell element with reduced integration and a large-strain formulation) with the dimensions $\sim 5 \mathrm{~mm} \cdot 5 \mathrm{~mm}$ were applied, in the upper section the S4R with the dimensions $\sim 40 \mathrm{~mm} \cdot 40 \mathrm{~mm}$ were used, two bands were connected with S3 elements (3-node, triangular, stress/displacement shell element). Total sum of elements are 67491. The adopted finite element mesh is shown in Fig. 4. 


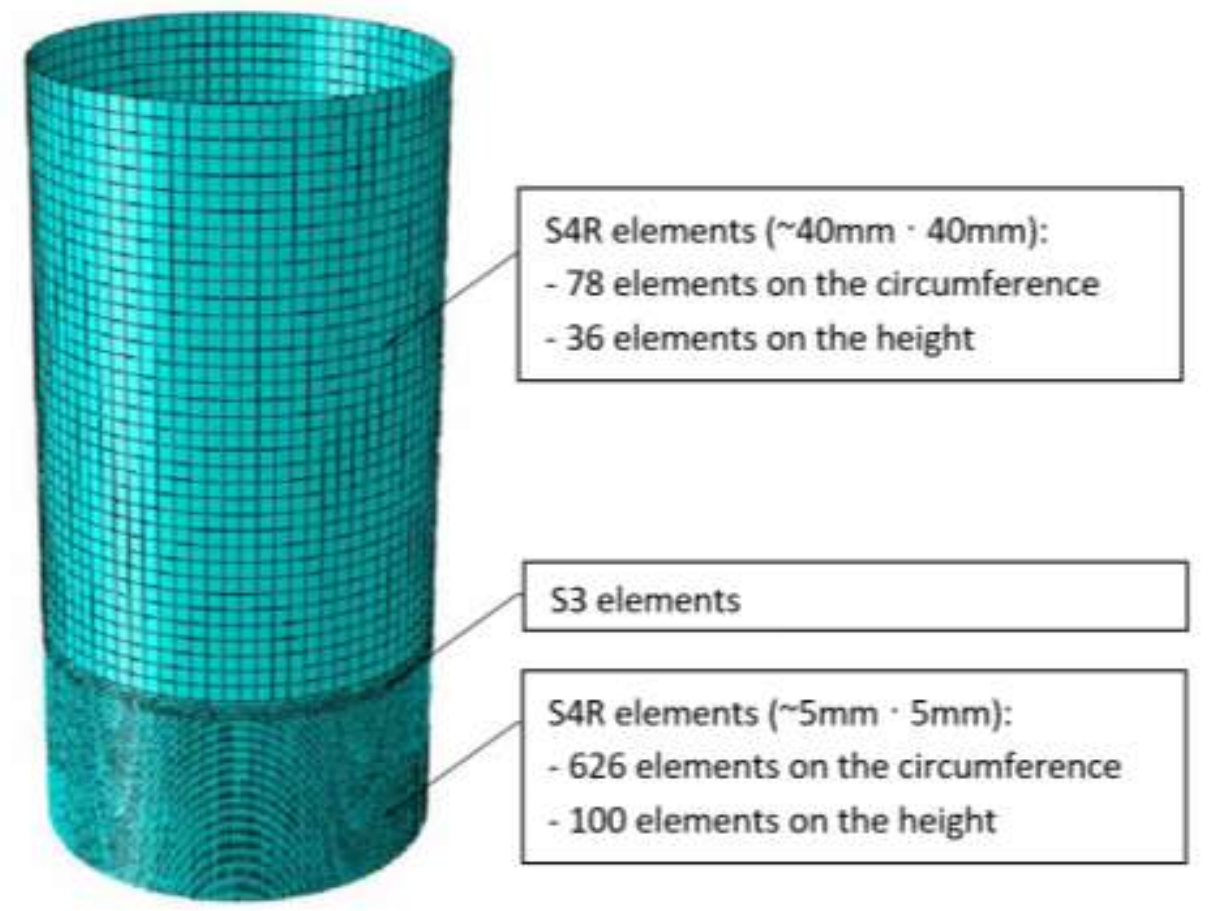

Fig. 4. Diagram of the adopted finite element mesh.

\section{ANALYSIS OF THE CYLINDRICAL SHELL USING THE FINITE ELEMENT METHOD.}

The article presents a solution to the problem of taking into account geometric imperfection in the shape of an eigen buckling form from a linear bifurcation analysis in cylindrical shells. In order to obtain a solution to this problem, all steps listed in point 1 were analysed. This procedure allowed us to observe the shell during more and more complex analyses and a better understanding of the problem. The articles Hotała (2014) [5] presented the whole procedure for calculating the capacity of the shell according to EN 1993-1-6 standard [1].

\subsection{LINEAR ELASTIC BIFURCATION ANALYSIS (LBA) OF A CYLINDRICAL SHELL.}

The linear elastic bifurcation analysis is based on the bending theory of thin-walled shells, it takes into account the ideal geometry and the theories of small displacements.

For the purposes of the article, an LBA analysis was performed with a given search parameter of the first 10 forms of shell stability loss, Fig. 5 shows the three first forms of stability loss - first of these forms is symmetrical, the rest are anti-symmetrical. For each of the forms of loss of stability, the load multiplier for the critical load was calculated, corresponding to 
the buckling of the shell, as well as its value. For the purpose of later calculations, the value of the critical load of loss of the first form was assumed as the initial value Ncr=75866N. Table 1 shows the critical load for the buckling value. All 10 forms of their eigen buckling form will be applied as initial geometrical imperfections in the GMNIA analysis.

Table 1. Critical load values for the first 10 normal modes for LBA analysis.

\begin{tabular}{|c|c|c|c|c|c|c|c|c|c|c|c|}
\hline \multicolumn{2}{|c|}{ Normal mode } & 1 & 2 & 3 & 4 & 5 & 6 & 7 & 8 & 9 & 10 \\
\hline $\begin{array}{c}\text { Critical load } \\
\text { multiplie } \\
\mathrm{r}\end{array}$ & {$[-]$} & 24.15 & 24.85 & 25.17 & 25.75 & 30.21 & 30.44 & 30.66 & 30.75 & 49.41 & 49.43 \\
\hline $\begin{array}{c}\text { Critical load } \\
\text { value }\end{array}$ & {$[\mathrm{N}]$} & $\begin{array}{c}7586 \\
6\end{array}$ & 78053 & $\begin{array}{c}7907 \\
1\end{array}$ & 80880 & 94911 & 95624 & 96315 & 96588 & 155220 & 155283 \\
\hline
\end{tabular}

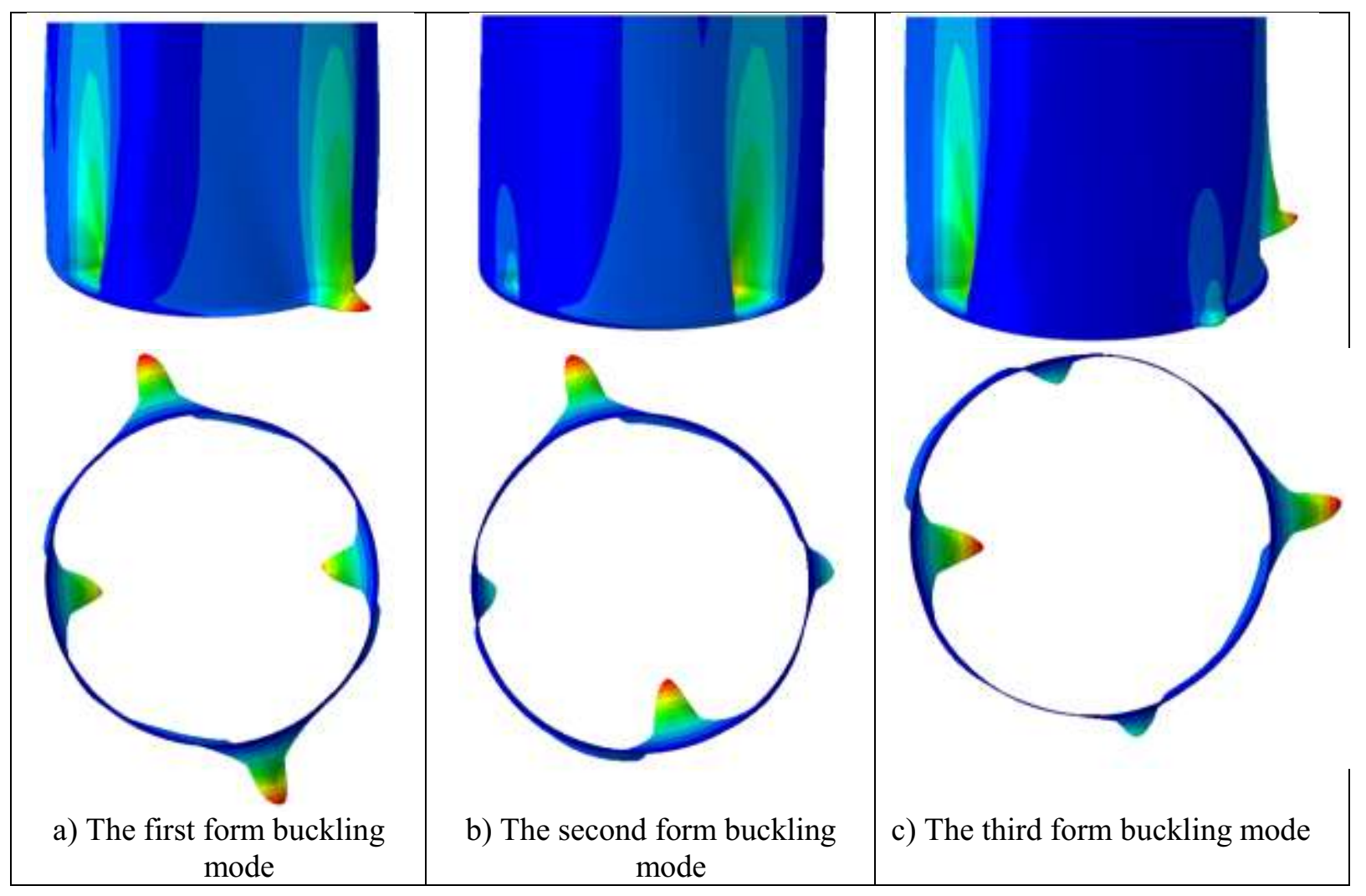

Fig. 5. Three first normal modes in the LBA analysis.

\subsection{MATERIALLY NONLINEAR ANALYSIS (MNA) OF A CYLINDRICAL SHELL.}

The materially nonlinear analysis uses the linear elastic-ideal plastic relations, as shown in Fig. 3. An analysis based on shell bending theory with perfect geometry and theories of small displacements. The strain shape for the MNA analysis is shown in Fig. 6, the shell behaves 
linearly to the load multiplier 29.12, which gives the critical load MNA=91616N. The linear shell behave in the MNA critical load can be read from Fig. 7, then the material becomes plasticized.
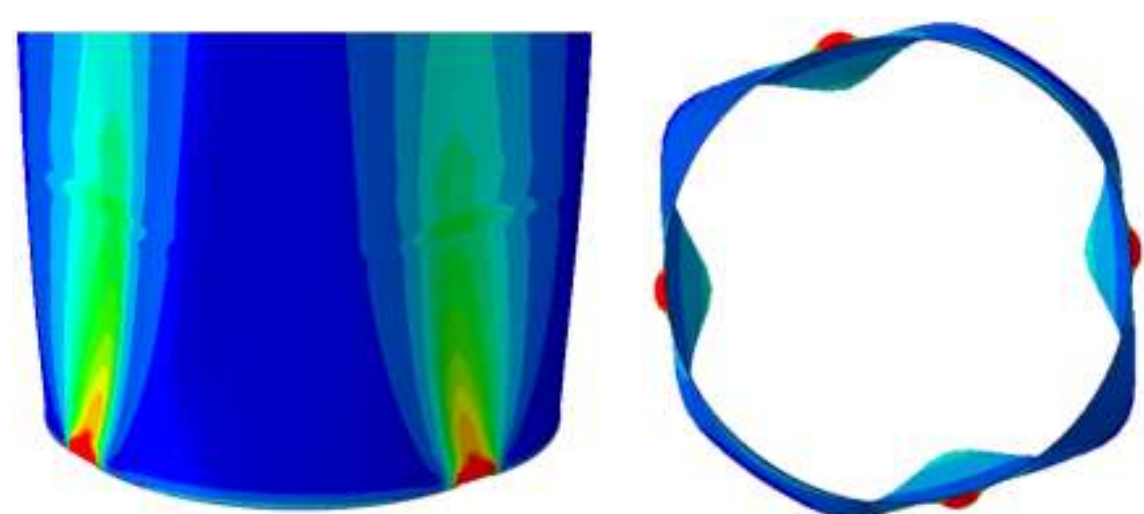

Fig. 6. Shape of shell deformation for the MNA analysis (Scale 25).

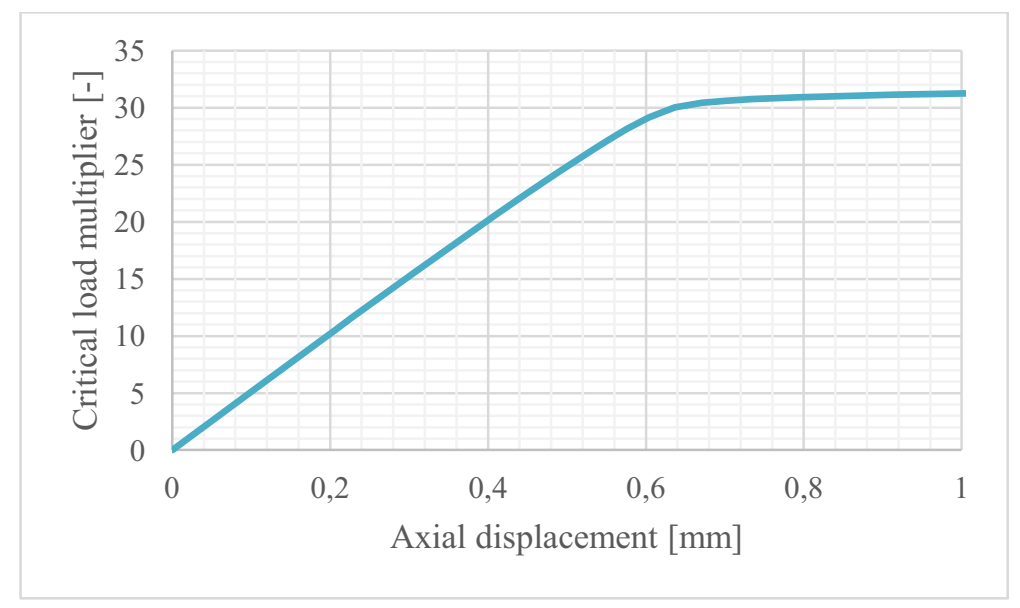

Fig. 7. Load-displacement equilibrium path for the MNA analysis.

\subsection{GEOMETRICALLY NONLINEAR ELASTIC ANALYSIS (GNA) OF A CYLINDRICAL SHELL.}

The analysis based on the assumption of a linearly elastic material feature is characterized by the load of the deformed structure in earlier increments. The bifurcation eigenvalue of the shell is checked at each load level. In the GNA analysis, the shell loses its stability at a load multiplier equal to 32.63 , which corresponds to the critical load GNA $=102518 \mathrm{~N}$, as shown in Fig. 8. With such load the shell has long exceeded the yield strength of steel, so it is purely hypothetical buckling. The buckling form in the GNA analysis is similar to the form from the MNA analysis. Fig. 9 illustrates the load-displacement equilibrium path of the tested shell, a 
rapid point of inflection of the graph was observed here, which corresponds to the loss of stability of the shell.
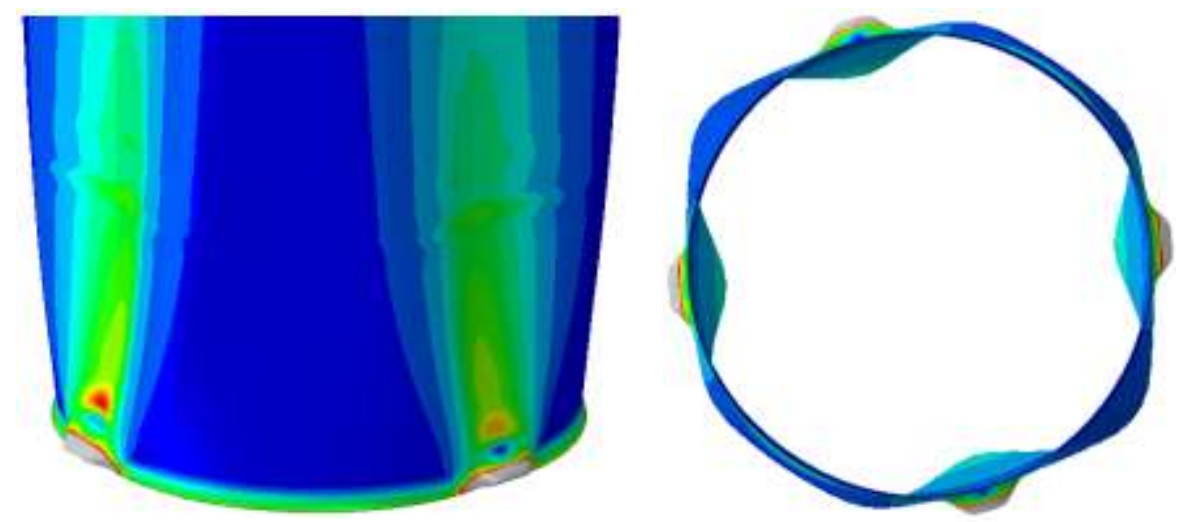

Fig. 8. Shape of shell deformation for the GNA analysis at loss of stability (Scale 25).

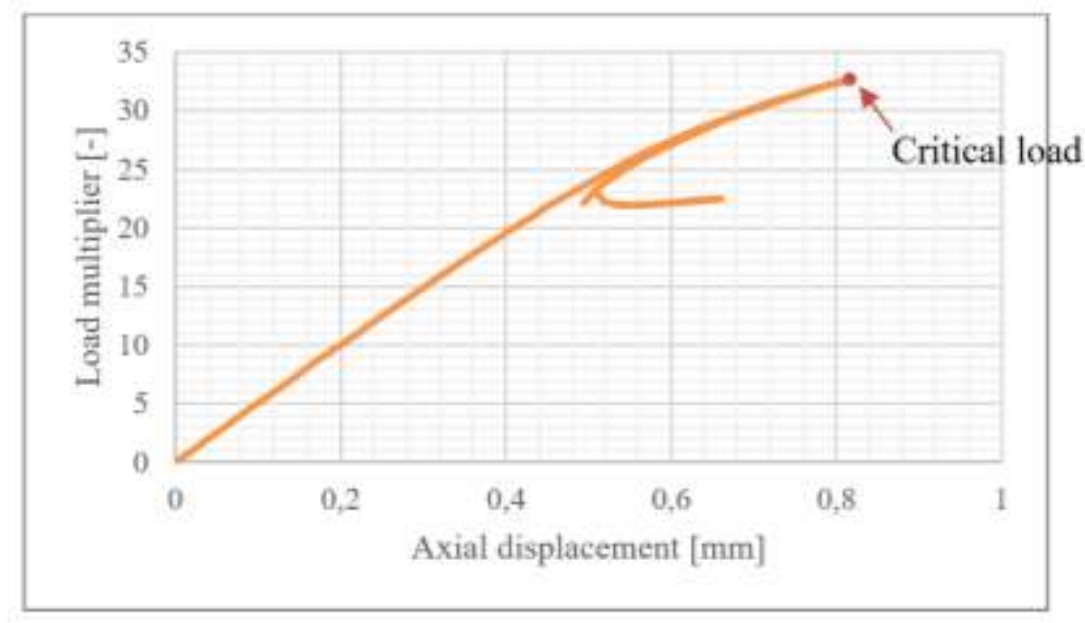

Fig. 9. Load-displacement equilibrium path for the GNA analysis.

\subsection{GEOMETRICALLY AND MATERIALLY NONLINEAR ANALYSIS (GMNA) OF A CYLINDRICAL SHELL.}

"The analysis based on the shell bending theory applied to the perfect structure, using the assumptions of nonlinear large deflection theory for the displacements and a fully nonlinear elastic-plastic-hardening maternal law, where appropriate, and which a bifurcation eigenvalue check is included at each load level" [1]. There is a noticeable drastic reduction in load capacity relative to the GNA analysis, which is $55 \%$. This is due to the fact that the load-displacement equilibrium path shapes for the GNA and MNA analysis were very similar. As it can be observed in Fig. 11, the GNA and GMNA analyses have a visible point at which the bifurcation shell loses 
its stability. The loss of stability of the GMNA analysis occurs at the value of the load multiplier equal to 18.13 , which corresponds to the critical load $\mathrm{Ncr}_{\mathrm{GMNA}}=56953 \mathrm{~N}$. In relation to the LBA analysis with the theoretically ideal shell, the capacity of the considered cylindrical shell is reduced to $75 \%$.
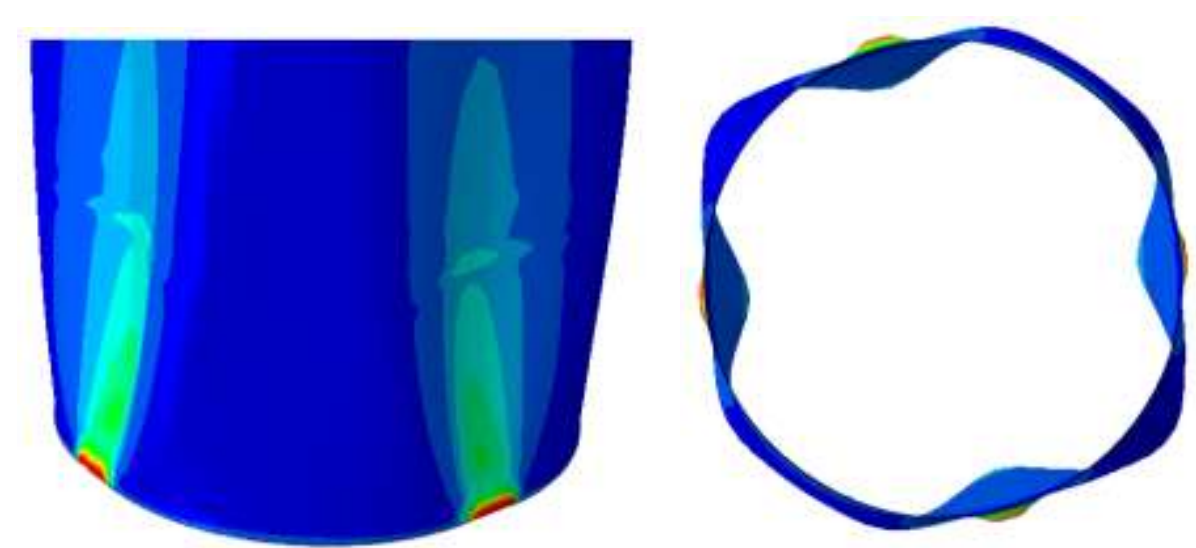

Fig. 10. Shape of shell deformation for the GMNA analysis at loss of stability (Scale x50).

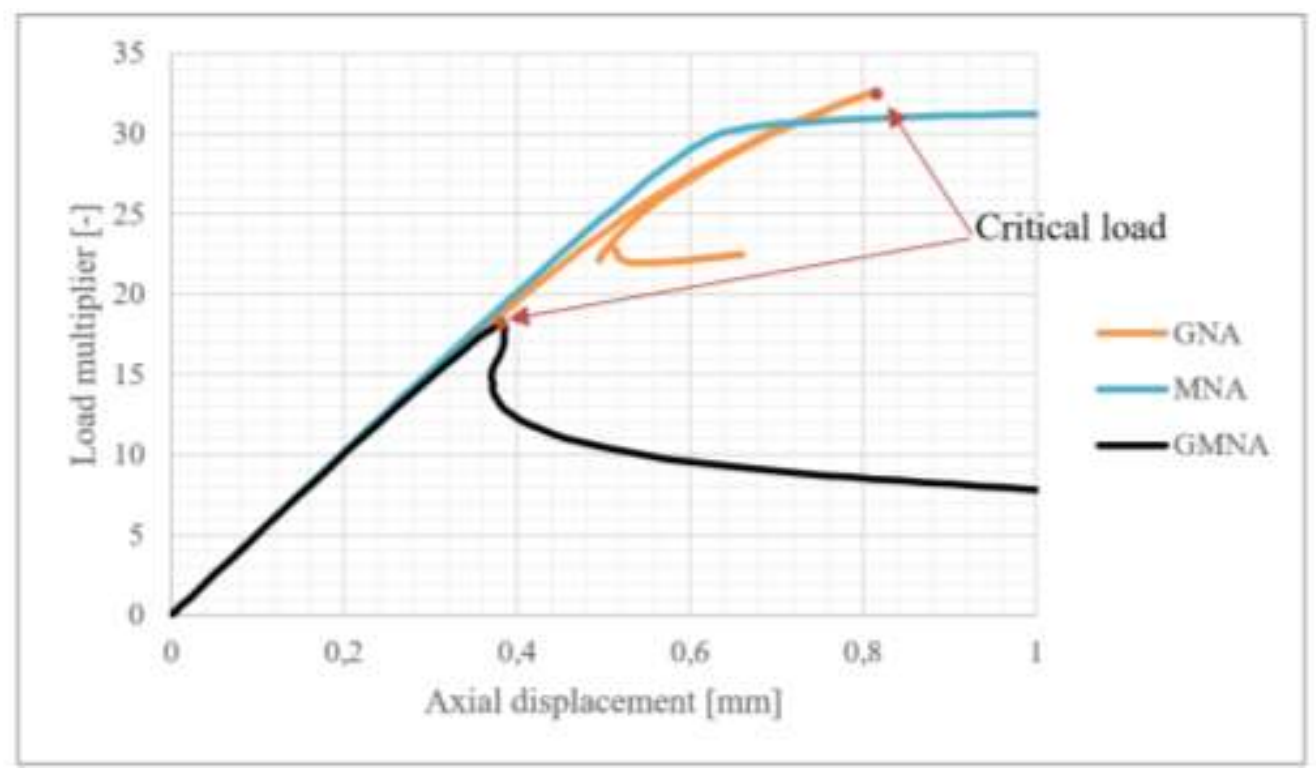

Fig. 11. Load-displacement equilibrium path for the GNA, MNA, GMNA analyses.

\subsection{ADOPTION OF THE GEOMETRICAL IMPERFECTION VALUE.}

The selection of the imperfection value is necessary for performing the final analysis, with which the studied shell will be loaded. The publication of Teng, J. G. (2004) [7] examined the impact of value of imperfections in relation to the wall thickness - the reduction of the shell's carrying capacity is much more influenced by the shape of imperfection than its value. The maximum value of imperfection based on the EN 1993-4-1:2009 standard [2] - the lowest class 
was adopted as the quality of manufacture. The displacement calculated according to the standard [2], which will imitate imperfections, is assumed as a value:

$$
\Delta \mathrm{w}_{\mathrm{o}, \mathrm{eq}}=0.625 \mathrm{~mm}
$$

\subsection{GEOMETRICALLY AND MATERIALLY NONLINEAR ANALYSIS WITH IMPERFECTIONS (GMNIA) OF A CYLINDRICAL SHELL.}

The analysis takes into account material (linear elastic-ideal plastic relations) and geometric (theories of large displacements) nonlinearities. The bifurcation stability is checked at each load level. The GMNIA analysis is the last phase of calculating the load capacity of the shell, reflecting the behaviour of the actual shell.

Ten shell numerical models were created that included initial geometric imperfections. Preliminary imperfections were included in the form of a deformed shell model from a linear elastic bifurcation analysis (point 3.1.). The value calculated in point 3.5 was adopted as the value of the strain in the radial direction. Fig. 12 shows the results of the GMNIA analysis for the first three models, it can be observed that only the first model is symmetrical, the other two are anti-symmetrical. Fig. 13 shows the load-displacement equilibrium path of ten numerical models when using the GMNIA analysis. Table 2 contains the values of critical load for which the shell loss of stability - the lowest value is reached by the shell with initial imperfections of the second normal mode. He value of the critical load at which the shell loses its stability in the GMNIA analysis with the most unfavourable imperfection in relation to the linear elastic bifurcation analysis is about $43 \%$, the critical load for the GMNIA analysis is Ncr, ${ }_{\mathrm{GMNIA}}=$ $32365 \mathrm{~N}$.

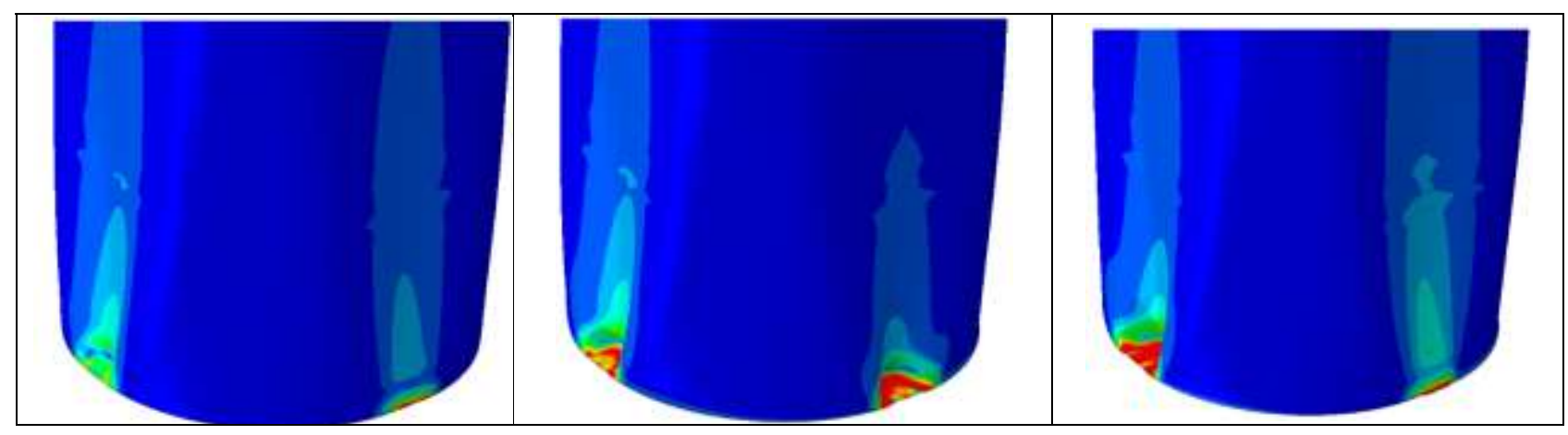




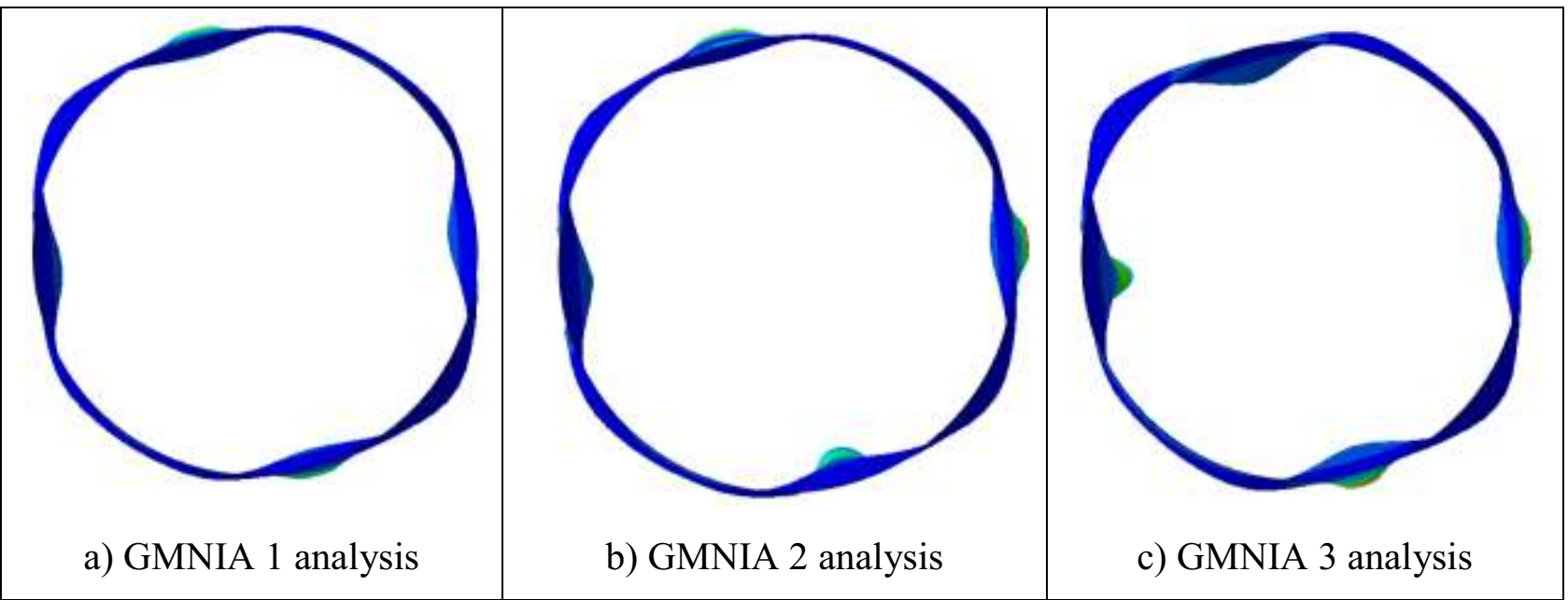

Fig. 12. Forms of loss of stability for GMNIA analyses.

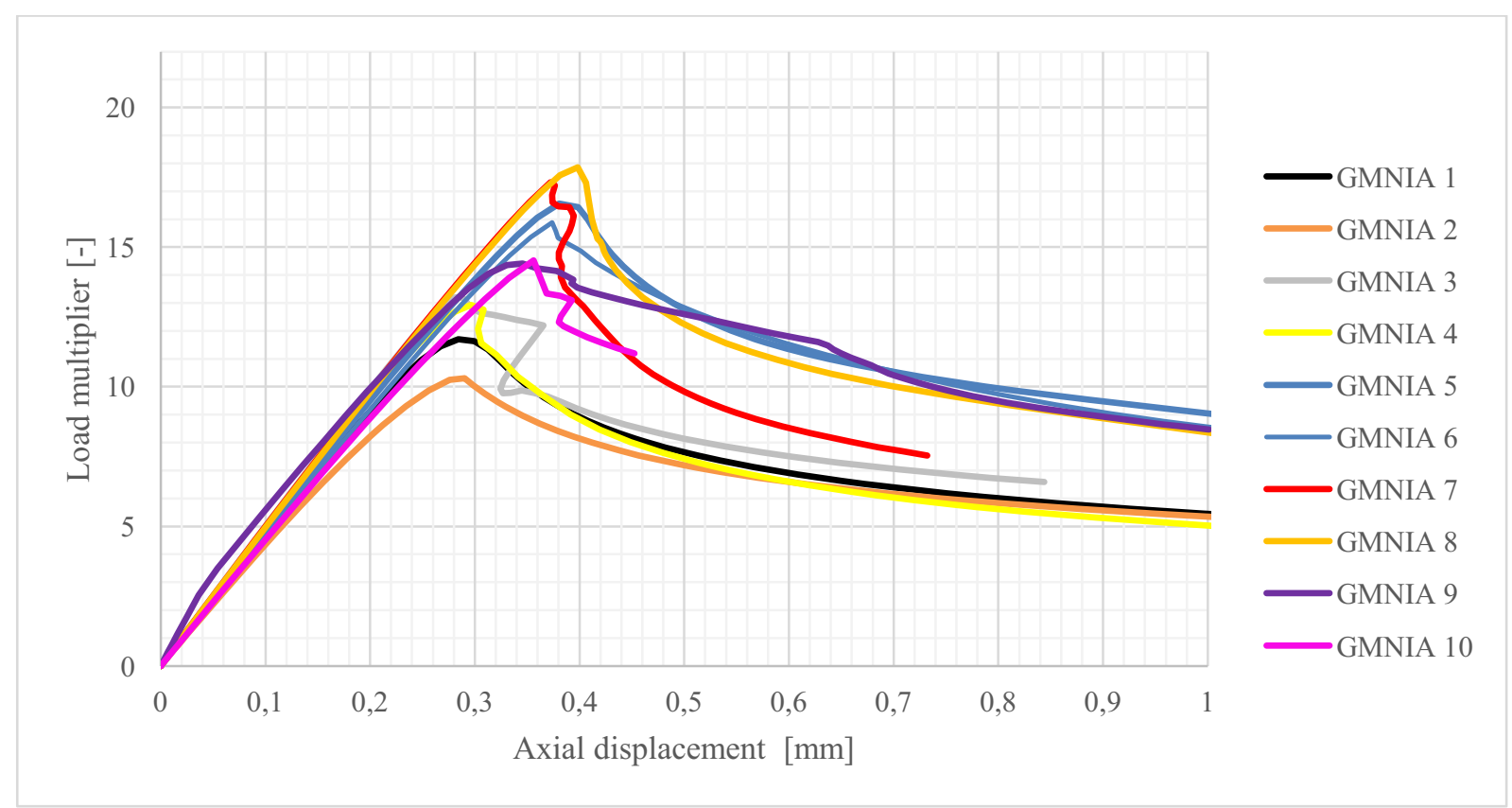

Fig. 13. Load-displacement equilibrium path for the GMNIA analyses.

Table 2. Critical load values for the first 10 normal modes for GMNIA analysis.

\begin{tabular}{|c|c|c|c|c|c|c|c|c|c|c|c|}
\hline \multicolumn{2}{|c|}{ Analysis } & $\begin{array}{c}\text { GMNIA } \\
1\end{array}$ & $\begin{array}{c}\text { GMNIA } \\
2\end{array}$ & $\begin{array}{c}\text { GMNIA } \\
3\end{array}$ & $\begin{array}{c}\text { GMNIA } \\
4\end{array}$ & $\begin{array}{c}\text { GMNIA } \\
5\end{array}$ & $\begin{array}{c}\text { GMNIA } \\
6\end{array}$ & $\begin{array}{c}\text { GMNIA } \\
7\end{array}$ & $\begin{array}{c}\text { GMNIA } \\
8\end{array}$ & $\begin{array}{c}\text { GMNIA } \\
9\end{array}$ & $\begin{array}{c}\text { GMNIA } \\
10\end{array}$ \\
\hline $\begin{array}{c}\text { Critical load } \\
\text { multiplier }\end{array}$ & {$[-]$} & 11.71 & 10.30 & 13.23 & 12,93 & 16.56 & 15.88 & 17.21 & 17.85 & 14.41 & 14.53 \\
\hline $\begin{array}{c}\text { Critical load } \\
\text { value }\end{array}$ & {$[\mathrm{N}]$} & 36775 & 32365 & 41561 & 40613 & 52032 & 49875 & 54061 & 56086 & 45281 & 45650 \\
\hline
\end{tabular}




\section{CONCLUSIONS}

The following conclusions were drawn on the basis of geometrically and materially nonlinear analysis with imperfections:

- The allowed use by the EN 1993-1-6 standard [1] of the form of imperfection and buckling of a linear elastic bifurcation analysis requires special attention of the designer. The first form of the buckling mode shapes from LBA does not have to be a shape of imperfections that reduce the load capacity in the GMNIA analysis.

- Taking into account the wrong form of buckling as a preliminary imperfection may increase the load capacity of the shell by several percent.

- Particular attention should be paid to the anti-symmetrical shape of the buckling. Including such a form as geometric imperfections may be more adverse.

\section{SUMMARY}

The numerical analysis is an excellent tool for assessing the load capacity of shells. The article analyses more complex calculations in subsequent steps. In the case of linear elastic bifurcation analysis, the value of the critical load at which the shell lost its stability was $\mathrm{Ncr}=75866 \mathrm{~N}$, it was assumed as a reference value, taking into account the geometric and material nonlinearity in the analysis reduced the maximum load at which the shell lost its bifurcation stability, according to the value $\mathrm{Ncr},{ }_{\mathrm{GMNA}}=56953 \mathrm{~N}$, which accounts for about $75 \%$ of the initial load capacity. The performance of the next analyses was aimed at the analysis of the structure, location of sites sensitive to local loss of stability and its direction. With this information, the effect of geometrical imperfection in the shape of eigen buckling form on the reduction of capacity of the cylindrical shell. The first 10 forms of normal modes from LBA analysis were adopted as initial geometrical imperfections. The article showed that adopting the first normal mode from the LBA analysis is not always a correct approach, the difference between the GMNIA analysis and the shape of imperfection from the first form of loss of stability in the LBA analysis and the second one (the most unfavourable one) is about $13 \%$. In the case of a numerical analysis, several forms of imperfection should be analysed at the design stage, paying special attention to the anti-symmetrical ones. The shell considered in the GMNIA analysis achieved a loss of stability at the Ncr,,$_{\text {GMNIA }}=32365 \mathrm{~N}$ critical load, which is approx. $43 \%$ of the bearing capacity compared to the initial reference point which was critical load calculated for linear-elastic shell model. 


\section{REFERENCES}

1. EN 1993-1-6:2009/A1:2017-07, Eurocode 3: Design of steel structures -- Part 1-6: Strength and Stability of Shell Structures

2. EN 1993-4-1:2009/A1:2017-08, Eurocode 3: Design of steel structures -- Part 4-1: Silos

3. EN 1993-1-1:2006/A1:2014-07, Eurocode 3: Design of steel structures -- Part 1-1: General rules and rules for buildings

4. Timoshenko, S. P., Gere, J. M. (1961). Theory of elastic stability. Mineola, New York: Dover Publications, inc.

5. Athiannan, K. and Palaninathan, R. (2004). Experimental investigations on buckling of thin cylindrical shells under axial compression and transverse shear, Sadhana, Vol. 29, Part 1, pp. 93-115.

6. Hotała, E., Skotny, Ł., Drużbiak, I., Boniecka, J., (2014). Analiza zachowania się stalowego płaszcza silosu wg różnych procedur normowych, Materiały Budowlane, nr 5/2014, pp. 73-75.

7. Teng, J. G.; Rotter, J. M., (2004). Buckling of thin metal shells, London ; New York : Spon Press.

8. Błażejewski, P., Marcinowski, J., (2014). A new approach to the buckling resistance assessment of pressurized spherical shells, Shell Structures: Theory and Applicatons, Volume 3, pp. 179-182.

9. Baran, W., (2014). Możliwości obliczeniowe a wymaganie wg Eurokodu 3 przy wyznaczaniu sił przekrojowych konstrukcji powłokowych, Budownictwo i Architektura, nr 13(2) (2014), pp. 143-151.

10. Cai, M.J., Mark, J., Holst, F.G. and Rotter, J.M. (2002). Buckling strength of thin cylindrical shells under localized axial compression, EM2002, 15th ASCE Engineering Mechanics Conference, Columbia University, New York.

\section{LIST OF FIGURES AND TABLES:}

Fig. 1. Model geometry.

Fig. 2. Shell load diagram.

Fig. 3. Linear elastic-ideal plastic relations. Source: EN 1993-1-1 - figure 5.8 [3].

Fig. 4. Diagram of the adopted finite element mesh.

Fig. 5. Three first normal modes in the LBA analysis.

Fig. 6. Shape of shell deformation for the MNA analysis (Scale 25).

Fig. 7. Load-displacement equilibrium path for the MNA analysis.

Fig. 8. Shape of shell deformation for the GNA analysis at loss of stability (Scale 25).

Fig. 9. Load-displacement equilibrium path for the GNA analysis.

Fig. 10. Shape of shell deformation for the GMNA analysis at loss of stability (Scale 50).

Fig. 11. Load-displacement equilibrium path for the GNA, MNA, GMNA analyses.

Fig. 12. Forms of loss of stability for GMNIA analyses.

Fig. 13. Load-displacement equilibrium path for the GMNIA analyses.

Table 1. Critical load values for the first 10 normal modes for LBA analysis.

Table 2. Critical load values for the first 10 normal modes for GMNIA analysis. 


\section{WPLYW IMPERFEKCJI GEOMETRYCZNYCH O KSZTALCIE POSTACI WLASNEJ WYBOCZENIA NA REDUKCJĘ NOŚNOŚCI POWŁOKI CYLINDRYCZNEJ}

Slowa kluczowe: Analiza numeryczna, powłoka cylindryczna, imperfekcje.

\section{STRESZCZENIE}

Podejście do analiz numerycznych w zakresie obliczeń nośności powłok cylindrycznych zostało zmodyfikowane przez wprowadzenie Eurokodów. Norma Eurokod 1993-1-6 umożliwia uwzględnienie imperfekcji o kształcie formy wyboczenia z liniowej sprężystej analizy bifurkacyjnej. W artykule przedstawiono wykorzystanie dziesięciu pierwszych form wyboczenia z liniowej sprężystej analizy bifurkacyjnej jako imperfekcji wstępnych. Przeanalizowano ich wpływ na redukcję nośności powłoki cylindrycznej. Obliczenia zostały przeprowadzone za pomocą metody elementów skończonych.

Received 10.06.2017

Revised 29.08.2019 